\title{
The Translation of Indonesian Reduplication into English
}

\author{
Clara Herlina Karjo, Menik Winiharti, and Muhartoyo \\ Bina Nusantara University, Jakarta, INDONESIA \\ e-mails: claraherlina@yahoo.com, menikwiniharti@yahoo.com,ymuhartoyoi@yahoo.com
}

\begin{abstract}
Every language has its own way to communicate its expression. Indonesian has reduplication such as pagi-pagi, cantikcantik, and jalan-jalan. The English translation of this reduplication is not *morning-morning, *beautiful-beautiful, and*walking-walking respectively. In this case, the translators should make an adjustment when they transfer the message of the Indonesian reduplication into English. This study investigates how Indonesian university students, teachers, and professionals translate the Indonesian reduplications into English. It explores the meaning and structure resulted from the translation. The participants are university students, lecturers and employees. They are given questionnaires in which they translate the Indonesian reduplication into English. The analysis involves the morphological, syntactic and semantic aspects of the translation, as well as the deviations that possibly occur in the translation.
\end{abstract}

Keywords: Translation, reduplication, meaning, structure, deviation

\section{INTRODUCTION}

Reduplication is a morphological process in which the root or stem of a word or a part of it is repeated. In many languages, reduplication is used in inflections to convey grammatical functions and in lexical derivations to create semantic forms (Nadarajan, 2006). There are two kinds of reduplication: full and partial reduplication. Full reduplication involves the exact repetition of the sound or word, while partial reduplication involves reduplication of only a part of a word.

According to Minkova (2002, p.136), most reduplications in English are partial reduplication which involves consonant ablaut or vowel alternation (e.g., riff raff, ping pong, chit chat, tip top), rhyme reduplication (e.g., hocus-pocus) and full reduplication (e.g., boo-boo). English reduplications have a certain form class and specific meaning. For example, chit-chat is a noun meaning a light conversation, and a verb meaning to talk informally or to gossip.

Similarly, Indonesian has also full reduplication, partial reduplication and imitative (ablaut) reduplication (Sneddon, 2010). However, the most prevailing reduplication in Indonesian is full reduplication. Unlike English, the meaning of Indonesian reduplication may vary even though the form class is the same. For example, noun reduplication can indicate plurality (buku-buku = 'books') or variety (di antara barang-barang dagangan = 'among various goods').
Translating Indonesian reduplication into English is not an easy matter for English users or learners. In some cases, people translate pagi-pagi and jalan-jalan into 'morning-morning' and 'walking-walking', which are definitely unacceptable since those are the literal translation of the Indonesian words. Larson (1998) calls this kind of translation as form-based translation which attempts to follow the form of the source language. Larson also proposes another kind of translation called meaning-based translation, which makes every effort to communicate the source language in the natural forms of the receptor language. Thus, in the case of pagi-pagi and jalanjalan, they are best translated into 'early in the morning' and 'take a walk' respectively. This kind of translation is also called idiomatic translation.

To translate Indonesian reduplications into English, the transfer of meaning (the semantic aspect) is not the only thing to consider. We must also consider the semantic and syntactic aspects so that the translations can convey the meaning of reduplications correctly in English. Newmark (1988) mentions that there are fourteen procedures that can be used by a translator in the translation process, two of which can be used to analyze the translation of Indonesian reduplications into English.

The first procedure is transposition. It is a translation procedure involving a change in the grammar from Source Language (SL) to Target Language (TL). For example, there is a shift of word class in the phrase 
'bahan kimia' into 'chemical material'. 'Kimia' is a noun while in English it becomes 'chemical' - an adjective. Thus, the first consideration to translate the reduplication is the syntactic aspect, i.e., whether the translation should carry the same word class as the source language.

The second procedure is modulation or shift of meaning. This might happen if there is a change of perspective, point of view or other meaning element. For example, the phrase 'Dear Sir' is translated as Dengan Hormat because Bahasa Indonesia as TL does not have the equivalence for that phrase. This meaning postulate (semantic factor) is the most important factor to consider. Even though the translation requires a modulation of meaning, the original message in SL should be conveyed.

The last factor, morphological factor, is not included in Newmark's translation procedure but it is related to the kind of translation mentioned by Larson's (1998) literal translation. It is obvious that translation that copies the form of SL is inappropriate. For example, merah-merah (merah $=$ 'red') cannot be translated directly as 'red-red'. Yet, when it is reduplicated as in the sentence Mangganya sudah merah merah, the translation is not 'the mangoes are red-red'. Instead, the more appropriate translation would be 'the mangoes are turning red'.

Wong (2004) mentions that language is a tool which people use to express meaning. Thus, one cannot claim to have a good understanding of a word without first understanding the meaning it expresses. For example, if someone says, ,'Dia masih kecil tapi sudah seperti tante-tante." (= 'She is still young but acts like aunty-aunty'). The reduplication of "tantetante" in this sentence means 'the behavior of middleaged women', which usually has negative implication. In translating this sentence into English or expressing this meaning in English, it is better to say "She is still a young girl, but she acts as if she were a flirtatious middle-aged woman"; instead of saying "She is still young but acts like aunty-aunty".

Not all English users/learners are able to translate Indonesian reduplications well into English, in the sense that the translations do not follow the form literally but convey the meaning correctly. This study analyzes the ability of three groups of English learners/users (students, lecturers and professionals) in translating Indonesian reduplications into English. Their translations will show their capability in understanding Indonesian reduplications and expressing them appropriately in English.

\section{METHODOLOGY}

This study was basically conducted in a qualitative approach. The purpose of this study was to find the respondents' ability in translating Indonesian reduplications into English. Thus the instrument used was translation test in which the respondents should translate 20 Indonesian sentences containing reduplications into English.

\section{Participants}

There were three groups of participants in this research. These three groups were chosen because they represented the language learners and the language users. The first group consisted of fifty students of Bina Nusantara University from all majors. They were the fourth semester students taking English as the compulsory subject for one semester. The second group was twenty lecturers of Bina Nusantara University from various faculties. They were all master graduates from different fields of study. The third group was thirty employees from Direktorat Jenderal Minyak dan Gas Bumi, Departemen Pertambangan Sumberdaya Mineral, and Departemen Perhubungan. They were all bachelor graduates with two to ten years of working experience.

\section{Research procedures and analysis}

The test consisted of twenty Indonesian sentences containing reduplications taken from various newspapers, magazines and novels. There were a total of twenty-three reduplications classified into nouns, adjective, adverbs and verbs. The participants had to translate twenty sentences. The participants could do these tests at home and used any available resources they had. The participants' translation results were then categorized according to the syntactic functions of the source text (Indonesian). Thus, the translations were classified under four sub-headings: the translation of nouns, verbs, adjectives and adverbs. The acceptability of the translation would be analyzed in terms of three aspects: syntactic, morphological and semantic. The main concern for the acceptability of the translation was the semantic aspect, i.e., whether the translation conveys the original meaning of the source language.

The next step was calculating the translation results of the three groups of participants. Their results were compared to see which group can produce better translations of reduplication. Finally, the mistakes committed by these three groups were also discussed to find out the underlying reasons why Indonesian reduplications were difficult to translate. 


\section{RESULT AND DISCUSSION}

The result is presented in Table 1. It shows the percentages of each group of participants who produced acceptable translations. For example, for the phrase (tidak bisa melakukan) apa-apa, 95\% of the lecturer group, or nineteen persons, produce acceptable translation for this phrase. Similarly, $100 \%$ or all fifty students, and $100 \%$ or all thirty employees were able to produce acceptable translations.

Table 1. Total results of the acceptable translation of reduplications (in percentage)

\begin{tabular}{|c|c|c|c|}
\hline Phrases & $\begin{array}{l}\text { Lecturer } \\
(\mathrm{n}=20)\end{array}$ & $\begin{array}{l}\text { Students } \\
(\mathrm{n}=50)\end{array}$ & $\begin{array}{c}\text { Employees } \\
(\mathrm{n}=30)\end{array}$ \\
\hline semata-mata hanya & 100 & 46 & 97 \\
\hline ide-idenya & 100 & 86 & 100 \\
\hline $\begin{array}{l}\text { (tidak bisa melakukan) apa- } \\
\text { apa }\end{array}$ & 95 & 100 & 100 \\
\hline secara diam diam & 95 & 100 & 93 \\
\hline jauh jauh hari & 95 & 88 & 93 \\
\hline mudah-mudahan & 95 & 98 & 93 \\
\hline nilai-nilai & 90 & 42 & 80 \\
\hline masing-masing & 90 & 98 & 97 \\
\hline malah marah marah & 85 & 64 & 57 \\
\hline seakan akan terkenal & 85 & 52 & 67 \\
\hline sehari-hari & 85 & 100 & 93 \\
\hline berulang ulang & 85 & 94 & 90 \\
\hline tahun-tahun sebelumnya & 75 & 86 & 90 \\
\hline diserang habis-habisan & 75 & 70 & 77 \\
\hline berkali-kali & 70 & 92 & 90 \\
\hline mengacung-acungkan pistol & 70 & 90 & 77 \\
\hline nggak mau main-main & 60 & 96 & 30 \\
\hline tindakan-tindakan & 55 & 90 & 77 \\
\hline (bola mata) berkaca-kaca & 35 & 46 & 63 \\
\hline mbok-mbok (jaти) & 25 & 46 & 17 \\
\hline benar-benar & 20 & 56 & 83 \\
\hline bekas-bekas jahitan & 15 & 0 & 13 \\
\hline sama-sama (sibuk) & 15 & 74 & 33 \\
\hline In Average & 70 & 75 & 74 \\
\hline
\end{tabular}

\section{Reduplication of Nouns}

There were seven reduplications of nouns. They were: apa-apa, tahun-tahun, nilai-nilai,bekas-bekas, mbokmbok, tindakan-tindakan, dan ide-ide. Noun reduplications in Indonesian usually have the meaning of plurality. In English, plural nouns are usually formed by adding morpheme $-s$ to the original noun. Thus, 'buku-buku' should be translated as 'books'.

(1) "Endang sudah tidak bisa melakukan apaapa," ucap Agung dengan suara lirih dan bola mata berkaca-kaca.

The word 'apa' in Indonesian is a question word meaning what, however, when it is doubled into apa$a p a$, it becomes a noun, meaning everything or anything. The word 'apa-apa' in this context, was best translated as 'could not do anything' to retain its original meaning and function. Table 1 shows that almost all participants could translate the word correctly, even though there were some varieties of sentence structure being used, such as could not do, can no longer do, barely able to do. Semantically, all translations were considered acceptable, since the main focus was the conveyance of the original meaning.

(2) Sebagaimana tahun-tahun sebelumnya, upacara peringatan Hardiknas dipimpin langsung oleh Mendikbud Mohammad Nuh.

The reduplication 'tahun-tahun' functions as plural form of 'tahun' ('year'). Thus in English the plural form is 'years'. To translate this word, we should also consider the context, i.e., 'tahun-tahun sebelumnya'. Thus, only three kinds of translations were considered acceptable, that is, 'previous years', 'the years before', and 'prior years'. The employees produced $90 \%$ accepted translation compared to the students (86\%) and the lecturers (75\%). A variety of 'many years ago' was not acceptable because the word 'ago' shows some time in the past, while 'previous' means happening before the present time. Thus, in terms of meaning, the time frame does not match. Another variety, 'every year before', was grammatically unmatched because 'every' should be followed by a singular noun 'year' instead of 'years'.

(3) Pada saat yang sama institusi pendidikan diharapkan benar benar dapat menjadi tempat persemaian nilai-nilai budaya dan jati diri bangsa.

The reduplication 'nilai-nilai' expresses plurality of the word 'nilai' ('value'), thus the English translation should be 'values'. Table 1 shows that most of the lecturers and the employees could translate the word correctly. They translated 'nilai-nilai budaya' as 'cultural values'. However, more than half of the students did not translate this phrase appropriately, because they only wrote "value", which was considered unacceptable since this word is singular. A double mistake occured in the phrase 'value culture', produced by two employees. It was translated without changing the word order and it was not pluralized.

(4) Kontroversi mencuat saat ketiga jenasah tiba di tanah air dan pihak keluarga curiga dengan bekas-bekas jahitan di tubuh mereka.

The phrase 'bekas-bekas jahitan' refers to the marks or scars caused by stitches in someone's body. Only three translations that were considered acceptable: 
'scars or stich marks', 'suture marks', and 'stitches marks', because the headword of this phrase was 'bekas-bekas' ("marks") and not the stitches. Thus, the semantic aspect of these translations was fulfilled if the original message was conveyed in the translations.

The other translations were not acceptable because the original meaning was not transferred in the translations. The main problem is they only translated part of the phrase, either 'bekas-bekas' or 'jahitan'. For example, $56 \%$ of the students translated the phrase as 'stitches' which only referred to 'jahitan', thus 'bekas-bekas' was not translated. Others translated it into 'scars', 'sign', or 'marks', which only referred to 'bekas-bekas'. Another problem was the choice of words. The word 'jahitan' referred to the stitch in a person's body, so only 'stitch' or 'suture' was suitable, whereas the word 'seam' or 'sew' referring to stitches to join two pieces of cloth was not acceptable. Thus, there seems to be cultural mismatch here, because the word 'jahitan' in Indonesian can be done both to the person's body or clothes.

\section{(5) "Akhirnya kami seleksi mbok-mbok jamu dari jalan," tutur Ratna.}

The word ' $m b o k$ ' is a Javanese word meaning 'mother'. However, when it is reduplicated, 'mbokmbok' may have pragmatic meaning as well as plurality to refer to any old ladies, usually of Javanese origin. Thus, when it is attached to the word 'jamu', the phrase 'mbok-mbok jamu' can mean 'old ladies who are selling Javanese herbal drinks'. The problem in translating this phrase is to find the right equivalence for the words ' $m b o k-m b o k$ ' and 'jamu' in English, since these two words are culturally loaded. Thus, a variety of translations occured, but when these words are combined, the results are not satisfying, or in other words the translations were unacceptable.

The results in 'accepted translation' (AT) show that there were two kinds of translation. First is those that maintained the noun phrase structure (Noun + Noun), such as 'traditional medicine hawker', 'jamu seller', 'traditional medicine female sellers', 'jamu vendor ladies'. The word 'hawker' actually does not convey the meaning that the seller is an old lady, but it is assumed that the readers had general knowledge that the seller of traditional medicine was usually an old lady. 'Jamu seller' was also acceptable if the word 'jaтu' was given a definition in the footnote. The second AT maintained the noun phrase structure with a slight modification (noun +of/for+ noun), such as 'old seller of jamu', and 'salesperson for herbal medicine'. In terms of meaning, the variety of 'salesperson' does not convey the meaning of ' $m b o k$ mbok', but this translation was still acceptable since the general meaning was close to the original meaning.

The 'unaccepted translation' (UT), on the contrary, resulted when the original meanings of ' $m b o k-m b o k$ ' or 'jamu' were not correctly or closely transferred. ' Jamu' is a healthy traditional drink made of specific herbs such as ginger and curcuma. However, if this word was only translated into 'herbs' or 'herbal', it did not convey the original message, because 'herbs' covered a bigger range of plants which were not used to make 'jamu'. A herbalist is a person who practice medication using herbs, but a 'jamu' seller cannot be considered as a herbalist. Another reason for the inacceptability of the translation is related to the word order in the noun phrase. For example, the phrase 'herbs from the mothers' clearly violated the original meaning of 'mbok-mbokjamu'.

(6) Kalau tidak ada tindakan-tindakan lain yang kita lakukan dengan penuh tanggungjawab maka perekonomian kita tidak akan kuat.

The phrase 'tindakan-tindakan' is showing plurality, thus the translation should be using plural noun, i.e., 'actions'. The word 'measures' is also acceptable since it has similar meaning with actions. The table shows that $90 \%$ of the students couldcorrectly translate this phrase, whereas the error occured mostly because it was not pluralized into 'actions'. Other unacceptable varieties included 'don't act' or 'don't perform'.

(7) Selanjutnya siswa wajib merealisasikan ideidenya tersebut.

This phrase also shows plurality, so the translation of 'ide-idenya' becomes 'his ideas'. Almost all could translate this phrase correctly, but there were seven students who did not put ' $-\mathrm{s}$ ' at the end of the word to make it plural.

\section{Reduplication of Verbs}

There were only three reduplications that can be considered as verb. These were 'main-main', 'mengacung-acungkan' and 'berulang-ulang'. These reduplications have the meaning of pragmatic accentuation for 'main-main' and repetition of action for 'mengacung-acungkan' and 'berulang-ulang'.

(8) "Mantep deh mau nikah. Kali ini nggak mau main-main deh," pungkasnya. 
The reduplication 'main-main' has a function of pragmatic accentuation, i.e., to emphasize the meaning of 'main' ('to play'). However, the phrase 'main-main' has two meanings in Indonesian, (1) having fun doing something enjoyable, and (2) not being serious. In this context, the meaning of 'mainmain' was 'not being serious'. For this phrase, $96 \%$ of the students got accurate translations. One translation retained the verb form, i.e., 'to play (around)', and another changed the verb into an adjective, i.e., 'be serious'.

Most of the other translations were uncceptable because the context was failed to be included in the choice of expressions. For example, the phrase 'mess around' means 'to make a place dirty' or 'to make problems'. So, if the context was about a relationship between a man and a woman, this phrase was inappropriate. It also goes for the phrase 'hangkypangky' which means inappropriate sexual activity. This phrase is not related to 'main-main'. Thus, the choice of words must also consider the context (the meaning of the whole sentence).

(9) Namun yang terjadi pengendara vespa itu malah marah-marah.

The word 'marah' is the adjective 'angry', but when it is reduplicated, 'marah-marah' becomes a verb. This word has two meanings: (1) getting angry over and over again/continuously, and (2) saying words showing anger. In this context, the meaning of 'marah-marah' was the second one, i.e., saying abusive words to show that someone is angry. This phrase could be translated by maintaining the adjective form 'angry' with the addition of the linking verb 'get' to become 'get angry', to mean 'reaching a certain condition/state of being angry'. The word 'angry' could also be replaced with its synonym, such as 'mad', 'pissed off' or 'furious'. For this phrase, the lecturers had the highest accurate translations.

The deviant translations for this phrase were caused by several reasons. First, they translated literaly 'marah-marah' into 'angry-angry' thus maintaining the word form (adjective-adjective). Second, they only translated with one adjective 'angry' which has a different meaning with 'getting angry'. The grammar was also incorrect, such as 'even exploding', 'become madness' and 'was angrily'.

(10) Pria itu berkali-kali memukul pengemudi motor dan tidak jarang pula mengacungacungkan pistol ke arahnya.

The phrase 'mengacung-acungkan' means repetitive action/continuation of the verb 'acung'. This phrase has two meanings: (1) to show one's hand , (2) to hold a weapon toward someone. In this context, the phrase 'mengacung-acungkan' refers to the second meaning. For this phrase, $92 \%$ of the students could translate correctly, whereas most of the deviant translations occured because of the wrong choice of words, i.e., inappropriate synonyms for the word 'mengacungkan' ('to brandish'). For example, the phrase 'point out the gun' means 'mention something (about the gun) to someone'. This is way off the original meaning.

(11) Seseorang dapat mengalami serangan prostatitis berulang-ulang.

The phrase 'berulang-ulang' is a verb meaning doing something repeatedly and continously. Thus the translation for this phrase can be 'repeatedly', 'many times', 'more than once'. Syntactically, there will be a change of word class to become an adverb repeatedly or an adjective 'repeated' (attack). The table shows that the students had the most acceptable translation compared to the other two groups.

The unaccepted translation, for example 'by any time' has different meaning from the original. 'Any time' means the action can happen at no fixed time. Contextually, the original sentence could mean like that, but it lacked the feature of repetition, thus this translation was not acceptable.

\section{Reduplication of Adjectives}

(12) "Endang sudah tidak bisa melakukan apaapa"ucap Agung dengan suara lirih dan bola mata berkaca-kaca.

The phrase 'berkaca-kaca' literally means 'have glasses", but when it is attached to its collocation 'eyes' or 'eyeballs', it has a metaphorical meaning. The phrase 'bola mata berkaca-kaca' means 'the eyes are wet with tears', describing the condition of the eyes after crying or when the person is trying to hold back tears. This phrase functions as an adjective which modifies the word 'bola mata' ('eyeball').

The accepted translation for this phrase is the one that can convey the meaning of 'mata berkaca-kaca'. Thus, there were several translations that could be accepted such as 'teary eyes', 'weepy eyes' or 'eyes filled with tears'. The table shows that the employees had more accepted translation (63\%) compared to students (46\%) and lecturers (35\%). These translations do not always use the same syntactic form and function. 'Teary' and 'weepy' function as adjective which is similar to the original words 'berkaca-kaca'. On the other hand, 'filled with tears' 
was a reduced adjective phrase and 'in tears' was a prepositional phrase.

The unaccepted translations were mostly due to the use of literal translation of ' $k a c a$ ' or 'glass', such as in 'glass eye', 'glassy eye' or 'glazed eye'. These translations mean 'eye made of glass' or 'eye which is shining like glass'. 'Glazed' means 'covered with glass or some liquid'. One employee wrote 'tear in the ball', which was far astray from the original meaning.

(13) Penumpang bisa mendapatkan harga murah untuk penerbangan kuartal pertama tahun ini, namun harus beli jauh-jauh hari.

'Jauh-jauh' is the reduplication of 'jauh' ('far') which modifies 'hari' ('day'). 'Jauh-jauh hari' refers to an adverb of time which denotes that something is done 'long before' something else happens. The accurate translation is 'far in advance'. However, in addition to 'far in advance', there are possible translations that could be accepted, such as: 'many days before',' long before', 'days before', 'days apart from', 'ages away before', 'far away days', 'very early', 'earlier', and 'days away'. The table shows that $95 \%$ of the lecturers had the acceptable translations, while employees and students had 93\% and 88\% respectively.

The unacceptable translations were due to the different messages that were conveyed, such as before and already before. These translations did not convey the message of 'jauh-jauh'. Moreover, the message of 'months before', 'early days', and 'very long time before' were far from the original message of 'jauhjauh hari'. In terms of syntactic function, 'jauh-jauh' in Indonesian is an adjective explaining the noun 'hari'. In the acceptable translations, most functions are of adverbs, such as 'far in advance', 'long before'and 'days before'. Thus, the syntactic function of the translation changes.

\section{Reduplication of Adverbs}

In the following example, if 'benar-benar' is literally translated into 'true-true' or 'right-right', it will have a totally different message; besides, it has no sense at all in English.

(14) Pada saat yang sama, institusi pendidikan juga diharapkan benar-benar dapat menjadi tempat persemaian nilai nilai budaya dan jati diri bangsa, ujarnya.

In Indonesian, the meaning of 'benar-benar' refers to an adverb which explains that something is 'really' or 'truly' done. Thus, there are several possible meanings which can be accepted, such as : 'really', 'truly', 'genuinely', 'totally', and 'completely'. 'Really' and 'truly' are the precisely accurate messages of 'benar-benar'. However, the original sense of 'totally' and 'completely' is 'entirely', while according to the context in the sentence they maintain the original message of 'benar-benar'. $83 \%$ of the employees showed that they had translated the phrase accurately, whereas only $56 \%$ of the students and $20 \%$ of the lecturers translated it correctly.

The inaccuracy of the translations was due to the different meanings, such as 'exactly', 'hopefully', 'true', and 'also'. They did not convey the original message of 'benar-benar'. With regard to the syntactic function, 'benar-benar' is an adverb which modifies the verb 'diharapkan'. The translations 'really', 'truly', 'totally', and 'completely' are also adverbs which explain the verb 'expected'. Therefore, the functions of 'benar-benar' and its English translations are exactly the same.

(15) Selain karena sama-sama sibuk, mereka berdua ingin menikmati masa pacaran pasca menikah.

The phrase 'sama-sama' cannot be translated literally into 'same-same'. 'Sama-sama sibuk' means 'both (people) are busy'. The accepted translation for this phrase should be the one that conveyed the meaning that described the condition that the two people were busy. Therefore, several possibilities of translations were accepted, such as: 'they (are) both busy', 'both of them are busy', 'both busy', and 'being equally busy'. The table indicates that the students had more acceptable translations (74\%) compared to the lecturers (15\%) and employees (33\%).

In terms of syntactic functions, 'sama-sama' is an adverb modifying the adjective 'sibuk'. Most of the acceptable translations above use 'both' which functions as pronoun as in 'both of them are busy', and conjunction as in 'they (are) both busy'. Additionally, another acceptable translation is 'equally', which is also an adverb explaining the adjective 'busy'. Thus, the syntactic function of 'sama-sama' in this case can either change or stay the same.

Some translations were unaccepted, such as 'same as', 'same busyness', and 'being busy each other'. These translations did not convey an equal message, either because 'sama-sama' was literally translated into 'same' or translated using inaccurate phrase, such as 'each other' and 'their own'. 
(16) Tapi Alice juga membantah bahwa pernikahannya dilakukan secara diam-diam.

The phrase 'secara diam-diam' in this context describes how the marriage has taken place. The sense of this phrase suggests that the marriage was not revealed to public. Therefore, the accepted translation for this phrase should be the one that conveys the meaning that the marriage had been done privately without being revealed to public. Several acceptable translations that can be seen in the table are 'secretly', 'in secret', 'silently' and 'quietly'. The table shows that all of the students $(100 \%), 95 \%$ of the lecturers, and $93 \%$ of the employees had translated the phrase 'secara diam-diam' accurately.

With regards to the syntactic forms and functions, 'secara diam-diam' in Indonesian is an adverb which explains the verb 'dilakukan'. The English translations 'secretly', 'silently', and'quietly' are also adverbs modifying the verb. However, the acceptable translations include prepositional phrases 'in secret' and 'in silent'. Additionally, 'not published to the community' and 'without telling anybody' are also acceptable translations. These ones do not belong to adverbs, yet they still convey the equal message. Thus, the syntactic function of the translation of 'secara diam-diam' may either remain the same or change. The unacceptable translation, on the contrary, was due to failure to convey the equal message. The phrases 'in quiet down' and 'quietly ceremony' convey different messages. They did not incorporate the sense that the marriage had been done in private or without being revealed to public.

(17) Banyak konsumen yang tertipu dengan obat yang menggunakan merek seakanakan terkenal.

In the sentence, 'seakan-akan' modifies the adjective 'terkenal'. It describes an unreal condition in which someone acts; thus, the acceptable translations should be those that denote the sense 'as would be the case if'. Most of the acceptable translations used 'as if', 'as though', 'like', 'seem', all of which described the sense 'seakan-akan'. Few translations used 'fake' which denotes the sense of being unreal or pretending. There was one participant using 'similar' in the translation. It did not denote the meaning of being 'unreal', although the intended sense expressed that it was not the real famous one. Table 1 shows that the lecturers led the results showing $85 \%$ of acceptable translations, while students had $52 \%$ and employees $67 \%$. In terms of syntactic functions, 'seakan-akan' belongs to an adverb modifying the adjective 'terkenal'. Parts of the translations 'as if', 'as though', 'like', are all conjunctions. However, 'seem' and 'look like' is a linking verb, while 'fake' and 'similar' are adjectives. Therefore, the syntactic function of the translations 'seakan-akan' has changed. The unacceptable translations were due to the different messages transferred. Most of them did not have the sense 'seakan-akan'. They only conveyed the sense 'terkenal', such as 'famous', 'famous brand', 'great names', and 'well-known brand'.

(18) Pria itu berkali-kali memukul pengemudi motor dan tidak jarang pula mengacung acungkan pistol ke arahnya.

The phrase 'berkali-kali' in the sentence explains the verb 'memukul'. It has the sense that 'memukul' ('hit') is performed many times or again and again. Therefore, the acceptable translations were those that conveyed the message that the 'hitting' was carried out repeatedly. Some of the acceptable translations were: 'repeatedly', 'many times', 'numerous time', and 'again and again'. Most of the students (92\%) translated 'berkali-kali' accurately, compared to employees (90\%) and lecturers (70\%).

In the source language, 'berkali-kali' is an adverb modifying the verb 'memukul'. In the target language, 'repeatedly' is also an adverb explaining the verb 'hit'. However, 'many times', 'numerous time', and 'several times' are nouns that are basically intended to explain the frequency of hitting. The unacceptable translation was due to the different messages. 'A couple of time' and 'again' do not indicate that the hitting is done repeatedly, whereas 'continuously' and 'keeps beating' convey the message that the hitting is performed without stopping.

(19) Kedepannya, strategi pemasaran tidak lagi semata-mata hanya menjual produk, tapi juga harus mengkomunikasikan sebuah nilai

'Semata-mata' in Indonesian usually collocates with 'hanya', and it is usually expressed in 'tidak sematasemata hanya' as found in the sentence. 'Sematamata' means 'only' or 'solely', which describes the condition that something happens without anything or anyone else involved. Therefore, the acceptable translations should be those that carry out the sense of 'only' or 'solely. The lecturers (100\%) and most of the employees (97\%) had translated the phrase accurately by using 'purely', 'merely', 'solely', 'only', and 'just' to express the sense of 'sematamata'. On the contrary, only $46 \%$ of the students accurately translated it. 
In terms of syntactic function, 'semata-mata (hanya)' is an adverb explaining the verb 'menjual'. The acceptable translations which are 'purely', merely, solely, only, and just, are also adverbs. In this case, the syntactic function of the original phrase remains unchanged. The unacceptable translations use 'must not focus on' and 'not even'. As the translations of 'tidak semata-mata hanya', they were accepted since they conveyed different messages.

(20) Kalah jumlah pemain membuat pasukan Roberto di Matteo itu semakin diserang habis-habisan oleh Barcelona.

'Habis-habisan', which modifies the verb 'diserang', describes the condition that the team was attacked overmuch. Thus, the translation should be one that conveys the message of 'overmuch',' too much', or 'in the excessive quantity'. The acceptable translations used 'all out', 'heavily', 'endlessly', 'roughly', 'totally', 'severely', 'completely', and 'vociferously'. These phrases were intended to convey the message 'habis-habisan'. Employees resulted in $77 \%$ for accurately translating the phrase, while lecturers and students resulted in $75 \%$ and $70 \%$ respectively. The unacceptable translations, on the contrary, were those that did not convey the message of 'habis-habisan'. They either had different sense such as 'fiercely', 'so much done', and more, or did not include the message 'habis-habisan' by any means.

Regarding the syntactic function, both in Bahasa Indonesia and English, the words are adverbs. 'Habishabisan' in Indonesian is an adverb modifying the verb 'diserang'. The English translations as 'all out', 'heavily', 'endlessly', 'roughly', 'totally', 'severely', 'completely', and 'vociferously' are all adverbs.

(21) Mudah-mudahan, masyarakat menerima kami.

The phrase 'mudah-mudahan' denotes the sense of hope or that something might happen as expected. Therefore, several acceptable translations are 'hopefully', hope', 'wish', and 'may'. Most participants have translated 'mudah-mudahan' accurately. Lecturers, students, and employees resulted in acceptable translations of 95\%, 98\%, and 93\% respectively. However, there were a few unacceptable translations because they conveyed different messages of 'mudah-mudahan'. For example, 'God will' did not represent the original message, since the SL did not involve God's will. In addition, although both 'hopeful' and 'to be hoped' used 'hope', they were placed incorrectly, so the intended message was not clearly transferred. In terms of syntactic function, 'mudah-mudahan' is an adverb modifying the whole sentence. The accepted translation 'hopefully' is also an adverb. However, 'hope', 'wish' and 'may' are verbs or modal verb. Thus, the syntactic function in this case can either remain the same or change.

(22) Rudi sehari-hari menikmati perjalanan dengan commuter line.

The phrase 'sehari-hari' is an adverb denoting that something happens every day. The acceptable translations for this phrase is 'every day' or 'daily'. Almost all participants could translate this word correctly. Syntactically, the word class is changed in the translation into an adjective 'everyday' or a determiner 'every day'. Thus, the corect way of writing should be 'every day'. A variety of 'day trip' was considered unacceptable because it only denoted a single trip, while according to the context Rudi does the trip every day.

(23) Saham dan obligasi pemerintah masingmasing mencapai 21 persen.

Actually, 'masing-masing' is a pronoun meaning 'each'. However, 'respectively', and 'individually' were also acceptable. The table shows that almost all participants could translate the word well. Syntactically, the translation maintain the word class of the original form, that is a pronoun, while 'respectively' and 'individually'are adverbs. The unacceptable translation turned out to be no translation or the use of both. Both means the compilation of two entities, while each denotes a single entity.

\section{CONCLUSION}

Indonesian reduplications are not easy to translate into English since the function, meaning and form of Indonesian reduplications are different from those of English. Thus, in translating the reduplications, one has to carefully analyze these three aspects in order to produce acceptable translations. A translation test given to one-hundred participants (fifty students, twenty lecturers and thirty employees) showed that their ability to produce acceptable translations of reduplications were not much different. The lecturers achieve $70 \%$ of acceptable translation, while the students and the employees achieve $75 \%$ and $74 \%$ respectively. These results indicate that having higher educational background does not guarantee better ability in translating Indonesian sentences (particulaly those containing reduplications) into English. Or in 
other words, the English competence of these three groups are basically similar.

As for the translation results, there are several reasons why the translations are not acceptable. First, there is no translation at all. Participants simply did not translate difficult words, such as 'nilai-nilai budaya' into culture. Second the original words are kept in the translation, for example 'mbok-mbok jamu' is still written as mbok-mbok jamu in the translation. Third, participants used incorrect word choice for example 'bekas-bekas' becomes 'scares' instead of 'scars'. Fourth, the grammar for the English expressions was incorrect, for example, 'ide-ide' into 'idea'. Finally, the original form was retained, or translating literally, such as 'marah-marah' becomes 'angry angry'.

\section{REFERENCES}

Larson, M. L. (1998). Meaning-based translation. Lanham: University Press of America.

Minkova, D. (2002). Ablaut reduplication in English: Criss-crossing of prosody and verbal art. English Language and Linguistics 6(1), 133-169.

Nadarajan, S. (2006). A cross linguistic study of reduplication. Arizona: University of Arizona.

Newmark, P. (1988). A textbook of translation . New York: Prentice Hall.

Sneddon, J. (2010). Indonesian reference grammar. St. Leonard: Unwin and Allen.

Wong, J. (2004). Reduplication of nominal modifier in Singaporean English: A semantic and cultural interpretation. World Englishes, 23(3), 339-354. 